\title{
Water quality of the reservoirs used for irrigation in São José dos Pinhais, Paraná State, Brazil
}

\author{
Qualidade da água de reservatórios utilizados para \\ irrigação em São José dos Pinhais
}

Tiago Miguel Jarek ${ }^{\mathrm{I}}$ Jorge Luiz Moretti de Souza ${ }^{\text {II }}$ Nerilde Favaretto ${ }^{\text {II }}$ Lucimeris Ruaro $^{\text {III }}$

ABSTRACT

Land use outside its agricultural potential and low vegetation cover in the watershed impair the quality of water used for irrigation and may contribute to the spread of pathogenic coliform bacteria. The objective of this study was to relate the quality of irrigation water with the intensity and type of land use and the rainfall in a vegetable-producing region of São José dos Pinhais, Paraná. Water samples were collected monthly in 2013 from two reservoirs and one preserved source. After collection, the samples were chilled in Styrofoam boxes and transported to the laboratory for analyses of the total and thermotolerant coliforms. Effect of land use was analyzed by probability estimation trees. High land use and weekly above average rainfall increased the probability of thermo tolerant coliforms exceeding the limit allowed under legislation. In regards to thermo tolerant coliforms in the analyzed period, the water from only one reservoir was in accordance with the legislation for the quality of water to irrigate vegetables that are consumed raw. Results of this study are an alert to the local government for the necessity of environmental preservation to maintain the water quality of the county.

Key words: coliform, watershed, land use.

RESUMO

O uso do solo fora da sua aptidão agrícola e a pouca cobertura vegetal na bacia hidrográfica prejudicam a qualidade da água utilizada para irrigação, podendo disseminar bactérias patogennicas do grupo coliformes. $O$ objetivo do presente trabalho foi relacionar a qualidade da água de irrigação como uso do solo (intensidade e tipo de uso) e precipitação pluviométrica, em uma região produtora de hortaliças de São José dos Pinhais, Paraná. As coletas ocorreram mensalmente no ano de 2013, em dois reservatórios e uma nascente preservada. Após as coletas, as amostras foram refrigeradas em caixas de isopor e posteriormente procedeu-se às análises de coliformes totais e termotolerantes. Os resultados do efeito do uso do solo foram analisados em árvores de probabilidade. O maior uso do solo e a precipitação pluviométrica semanal acima da média aumentam a probabilidade dos coliformes termotolerantes estarem acima do permitido pela legislação. Para o período analisado e considerando os coliformes termotolerantes, apenas a água de um dos reservatórios estudados está de acordo com a legislação para ser utilizada para irrigação de hortaliças que são consumidas cruas. Os resultados obtidos são um indicativo para o poder público local quanto à necessidade da preservação ambiental e da conservação da qualidade da água na região.

Palavras-chave: coliformes, bacia de drenagem, uso do solo.

\section{INTRODUCTION}

The value of horticulture production in Paraná State reached 2.48 billion reals in 2012 (SEAB, 2014), and São José dos Pinhais is the largest horticulture producer in the region of Curitiba (RMC), with production that reached 216 million reals in 2012. For horticulture in this region, sprinklers are the most used irrigation systems (SANTOS \& BERTOTTI, 2009).

Disagreement between land use and agricultural potential and riparian vegetation absence in drainage basins worsens water quality with the diffusion of pollution to surface waters (GONÇALVES et al., 2005). Levels of contamination

\footnotetext{
'Pós-graduação em Agronomia e Produção Vegetal (PGAPV), Setor de Ciências Agrárias, Universidade Federal do Paraná (UFPR), Rua dos Funcionários, 1540, Juvevê, 80035-050, Curitiba, PR, Brasil. E-mail: tiagomiguel87@yahoo.com.br. Corresponding author.

IDepartamento de Solos e Engenharia Agrícola, Universidade Federal do Paraná (UFPR), Curitiba, PR, Brasil.

IIIDepartamento de Fitotecnia e Fitossanitarismo, Universidade Federal do Paraná (UFPR), Curitiba, PR, Brasil. 
are related to the type of soil use and the position in the drainage basin (SANTOS \& BERTOTTI, 2009). In agricultural areas, nutrient contamination is correlated with the seasonality of rainfall and the type of fertilization used because of runoff (GONÇALVES et al., 2005, OLIVEIRA et. al., 2008). Intensive soil management reduces aggregate stability, which results in increased erosion and transport of pollutants associated with sediments into the surface waters (GONÇALVES et al., 2005).

Several studies find that the quality of irrigation water in different regions of the country is inadequate for use because of high concentrations of total and fecal coliforms, as well as Escherichia coli (BONILHA \& HAWK., 1994; SILVA et al, 2010). Although the effects of land use in agricultural areas on the quality of irrigation water have not been sufficiently studied, the relation between precipitation and land use for pasture is established for contamination with total coliforms and solids (PINTO et al., 2009).

Resolution 357 of 2005 (CONAMA) establishes the following requirements for irrigation water intended for vegetables that are eaten raw: $i$ ) the maximum coliform limit is 200 fecal coliforms per $100 \mathrm{~mL}$ in $80 \%$ of samples (at least six samples); $i$ ) the maximum turbidity is $40 \mathrm{NTU}$; iii) the maximum concentration of total dissolved solids is $0.5 \mathrm{mg} \mathrm{mL}^{-1}$; and $i v$ ) the $\mathrm{pH}$ should be between 6.0 and 9.0.

Fecal coliforms are in the feces of warmblooded animals and are also found in soils, on plants and in other uncontaminated environments (CONAMA, 2005). Thus, fecal coliform bacteria are reported in areas that are not directly contaminated by fecal material.

The aim of this study was to relate irrigation water quality with land use (intensity and type) and rainfall in the horticultural areas of São José dos Pinhais, Paraná State, Brazil.

\section{MATERIALS AND METHODS}

The research was conducted in São José dos Pinhais-PR, at $25^{\circ} 35^{\prime} \mathrm{S}, 49^{\circ} 07^{\prime} \mathrm{W}$ and 933 meters. According to the Koppen classification, the region is a $\mathrm{Cfb}$ climate type, with annual rainfall between 1,600 and $1,800 \mathrm{~mm}$ and no dry season (IAPAR, 2014).

The soils were classified according to the Brazilian System of Soil Classification (EMBRAPA, 2006) methodology, which included a morphological description, chemical analysis and particle size determination. The analyses were performed in the Departamento de Solos e Engenharia Agrícola (DSEA), of the Universidade Federal do Paraná (UFPR).

Maps were designed for the land use and the slopes of the watersheds with the use of aerophotogrammetric letters, scale 1:20000, which is available in COMEC (State System PlanningCoordination of the Metropolitan Region of Curitiba). The geographical coordinates were recorded with an on-site GPS device. Idrisi software was used to process the information.

Water samples were collected in two reservoirs and in the natural source (Figure 1): reservoir "B" was in a drainage basin with low land use; reservoir " $C$ " was in a drainage basin with high land use; and the preserved natural body of water was in a drainage basin that was used as a control (Table 1). A single topographic divider separated the drainage basins for each sample location. This dividing point was carefully selected to avoid interference between watersheds and to allow rapid sampling. Monthly samples were collected in 2013 between February and September at 3:30PM and between October and January at 4:30PM (because of daylight saving time) following the recommendations of previous study (JAREK, 2014).

The water temperature and $\mathrm{pH}$ were measured with a thermometer/pH meter (Lutron $\mathrm{PH}-$ $206^{\circledR}$ ), and the air temperature and relative humidity (RH) were measured with a digital thermohygrometer $\left(\right.$ Inconterm $^{\circledR}$ ) when the water was sampled. The water flows in reservoir " $\mathrm{B}$ " and the natural water body (two repetitions) were directly determined at the flow of water with a bucket and a chronometer, and for the natural source, a small dam was installed that contained a rectangular output to facilitate the water sampling. The float method was used for tank "C", with the water piped into rectilinear portions with concrete pipes. The flow rate was estimated with the following universal equation:

$$
Q=V A
$$

Where $Q$ is the flow rate $\left(\mathrm{m}^{3} \mathrm{~h}^{-1}\right), V$ is the speed $\left(\mathrm{m} \mathrm{h}^{-1}\right)$, and $A$ is the area of the flow $\left(\mathrm{m}^{2}\right)$.

The rainfall was measured with a pluviometer, which was installed at $1.5 \mathrm{~m}$ above ground close to the sample sites. The daily readings were accumulated for seven days.

The turbidity was measured using a turbidimeter (Quimis ${ }^{\circledR}$ Q-279PiR-TCR) with the Nephelometric method. To determine total dry solids, approximately $40 \mathrm{~mL}$ of unfiltered water samples were dried at $103-105^{\circ} \mathrm{C}$ in beakers until complete evaporation of the water. The conductivity 


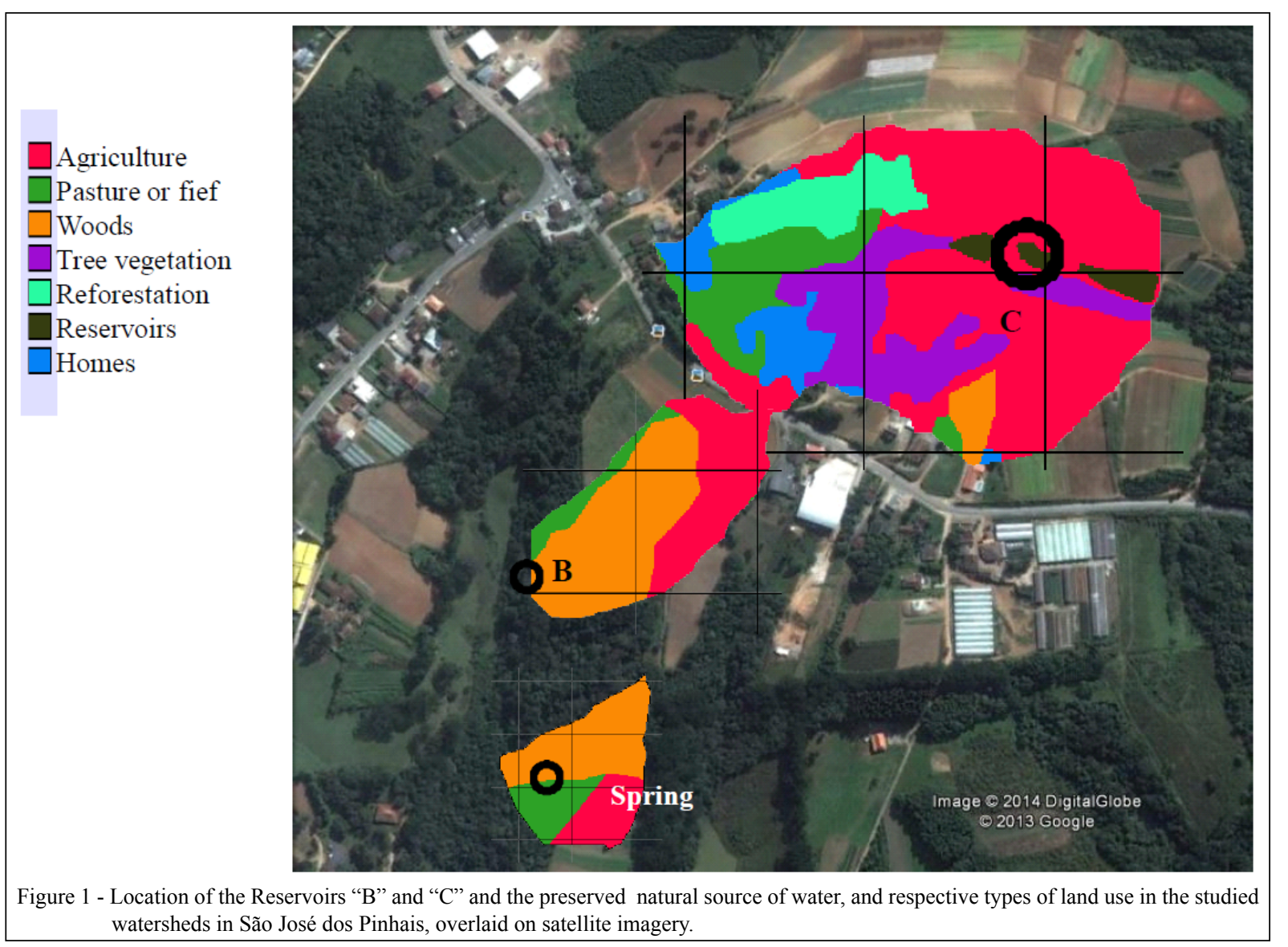

of the bottled samples was directly measured using a conductivity meter (Schott ${ }^{\circledR}$ Handylab LF1)

The analyses of the total and fecal coliforms were conducted with the Multiple Tubes method (APHA, 1992). The microbiological analyses were initiated less than $24 \mathrm{~h}$ after collection.

The soluble reactive phosphorus was analyzed with the Ascorbic Acid method. The samples that were frozen after sampling were thawed approximately $24 \mathrm{~h}$ before the analyses and then filtered through a 0.45 micrometer mesh.
After constructing a standard calibration curve, the analyses were performed with a spectrophotometer (APHA, 1992).

The effect of land use on water quality was analyzed with nonparametric statistics and a tree of nature and interested probability (SOUZA, 2013). The analyses considered land use in the watershed (percentage and type), precipitation and fecal coliforms. The following criteria were established. First, the drainage basin of reservoir " $\mathrm{C}$ " had areas of intensive agricultural use and areas of low forest use,

Table 1 - Geographic coordinates of the local collection of water samples, area and type of land use of studied watersheds in São José dos Pinhais.

\begin{tabular}{|c|c|c|c|c|c|c|c|}
\hline \multirow{2}{*}{ Local } & \multirow{2}{*}{ Coordinates ${ }^{(1)}$} & \multirow{2}{*}{$\begin{array}{c}\text { Total area } \\
\text { (ha) }\end{array}$} & \multicolumn{5}{|c|}{---Land use (ha)--- } \\
\hline & & & Agriculture & Woods & Pasture & Homes & Others \\
\hline Natural body of water & 0688511 E e $7167909 \mathrm{~N}$ & 1.48 & 0.37 & 0.80 & 0.31 & 0.0 & 0.0 \\
\hline Reservoir “B” & 0688472 E e $7168082 \mathrm{~N}$ & 2.15 & 0.75 & 1.23 & 0.18 & 0.0 & 0.0 \\
\hline Reservoir "C" & 0689027 E e $7168399 \mathrm{~N}$ & 14.92 & 7.76 & 4.09 & 157 & 1.09 & 0.41 \\
\hline
\end{tabular}

\footnotetext{
${ }^{(1)} \mathrm{E}$ - East e N - North.
} 
and it was classified with intensive use of the soil (Ui) (Figure 1 and Table 1), whereas the drainage basin of the natural body of water had little land use $(\mathrm{Pu})$. The drainage basin of reservoir "B" was classified as protected use (Ud). Second, rainfall values were accumulated for weekly periods, with a total of 52 values throughout the year. From the average of the 52 weekly values $(43 \mathrm{~mm})$, two groups of accumulated rainfall, which occurred seven days before collection of water samples, were established as follow: Ppi, with values lower than the annual average of $43 \mathrm{~mm}$, and Pps, with values higher than the annual average of $43 \mathrm{~mm}$. Third, the fecal coliforms were classified into two groups: $\mathrm{Cr}$, with values above the allowed values in Resolution 357 of 2005 from CONAMA, and $\mathrm{Ca}$, with values in accordance to the resolution.

Tukey's tests $(\alpha=0.05$ probability $)$ and ANOVAs were performed using Assistat 7.7 software, with the variables pectolytic bacteria, total coliforms, fecal coliforms, conductivity, soluble reactive phosphorus, $\mathrm{pH}$, total solids and turbidity.

\section{RESULTS AND DISCUSSION}

The soil in the study area is a dystrophic abruptic, yellow argisol. Because of the physical properties of abrupt textural change, the infiltration of water is low, and therefore, the area is prone to surface erosion (SANTOS \& RIBEIRO, 2000).

The watershed of the natural source had higher coverage with native vegetation $(75.2 \%)$, and was better preserved than the other watersheds (Figure 1). The catchment area for reservoir " $\mathrm{B}$ " was also well preserved, with $65.1 \%$ forest cover. The drainage basin of reservoir "C" was the largest (14.92ha), and most of the area was used for agriculture (7.76ha). Crops are located close to reservoir " $\mathrm{C}$ ", and only 1.86 ha of the watershed was covered with forest.

A riparian forest occupied $57 \%$ of the drainage basin area of reservoir " $\mathrm{B}$ " and acted as a filter to prevent sediment transport in runoff. In the watersheds studied, more than $50 \%$ of the slopes were easily erodible, with greater than $13 \%$ declivity. Runoff contributes to erosion, particularly in areas with soil disturbance and without conservation practices (LEPSCH, 1991).

The rainfall (cumulative seven days before the collection of water samples) and the most probable number of total coliforms per $100 \mathrm{~mL}$ (NMP $\left.100 \mathrm{~mL}^{-1}\right)$ were highly correlated $(\mathrm{R}=0.85)$. Because of the effect of intensive land use, which contributed to the contamination of water, the rainfall before sampling was a better reflection of the water quality than the water flow. For example, the water flow may remain high when there is no rain because of soil storage or decrease after heavy rainfall in small watersheds. Moreover, when the data were not collected daily, a correlation was not detected between water flow and runoff. The use of the water in the reservoirs for irrigation also contributed to the low correlations between water flow and precipitation, particularly in months with intensive agricultural activity that required irrigation.

During the periods of heaviest rainfall before sampling, the numbers of total and fecal coliforms increased. In reservoir " $C$ ", the catchment area with the highest agricultural use, the increase of coliforms in $100 \mathrm{~mL}^{-1}$ was greater than that in tank "B" or in the protected natural body of water (Figure 1).

From the decision tree of nature (Figure $2 \mathrm{a}$ ), zero probability of contamination by fecal coliforms (Cr) was conditioned on accumulated precipitation above $43 \mathrm{~mm}$ (Pps) intersecting with low land use $(\mathrm{Pu}): \mathrm{P}(\mathrm{Cr} \mid \mathrm{Pps} \cap \mathrm{Pu})=0$. With the protected use watershed (Ud), the probability of contamination was 20\%: $\mathrm{P}(\mathrm{Cr} \mid \mathrm{Pps} \cap \mathrm{Ud})=20 \%$. For the intensively used watershed (Ui), the probability of contamination was 75\%: $\mathrm{P}(\mathrm{Cr} \mid \mathrm{Pps} \cap \mathrm{Ui})=75 \%$. Thus, the use of $\mathrm{Pps}$ in the analyses increased the probability that fecal coliforms would occur at levels above those allowed $(\mathrm{Cr})$ by resolution 357 of 2005 (CONAMA) (Figure 2a).

The decision tree of interested probability (Figure 2b) determined the influence of intensive land use (Ui, reservoir "C" $)$, and $\mathrm{P}(\mathrm{Ui} \mid \mathrm{Pps} \cap \mathrm{Cr})=90.54 \%$ to $16.57 \%$ of the analyses with contamination after rainfall (Pps $\cap \mathrm{Cr}$ ). Land used out of its agricultural production potential is one of the decisive factors in the contamination process of surface water, which is primarily influenced by runoff water (GONÇALVES et al., 2005). Notably, however, $\mathrm{P}(\mathrm{Cr} \mid \mathrm{Ppi} \cap \mathrm{Pu})=$ $62.5 \%$. According to the fecal coliform definition, the bacteria in the feces of homeothermic animals can also be found in the soil, plants or other environments not directly contaminated by fecal matter (CONAMA, 2005). Therefore, the origin of fecal coliforms found in the natural body of water was explained because the probability of fecal coliforms found above that allowed in a Pps condition (accumulated rainfall that occurred seven days before the collection of water samples above the average of $43 \mathrm{~mm}$ ) was zero: $\mathrm{P}(\mathrm{Pu} \mid \mathrm{Pps} \cap \mathrm{Cr})=0.0$ (Figure $2 \mathrm{~b}$ ). A large bacterial population developed because of the decomposition of large amounts of organic material deposited by vegetation, which increased the biological activity and availability of nutrients. For example, the 


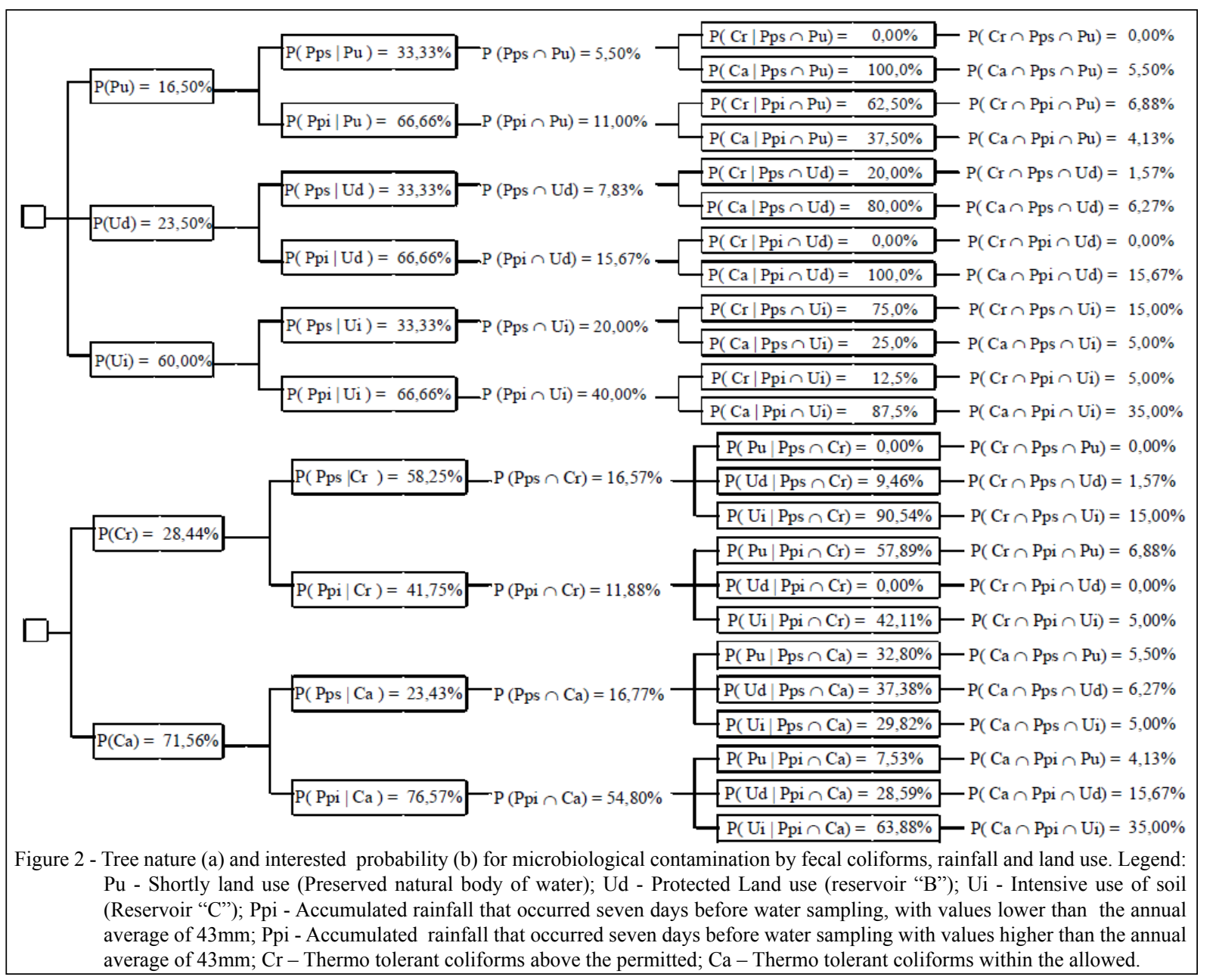

reactive soluble phosphorus content was statistically higher ( $\alpha=0.05$ level of probability) than that in other locations. In the Pps situation, the fecal coliform contamination was the highest in the areas with the greatest use of the soil. In the event of "Ppi $\cap \mathrm{Cr}$ " (Ppi: accumulated rainfall that occurred seven days before water sampling below the average of $43 \mathrm{~mm}$ ), the situation was not well defined because of the small number of events during the study period in the areas of protected (Ud, reservoir " $\mathrm{B}$ ") and intensive (Ui, reservoir " $\mathrm{C}$ ") use of soil. Therefore, $\mathrm{P}(\mathrm{Pu}$ $\mathrm{Ppi} \cap \mathrm{Cr})=57.89 \% ; \mathrm{P}(\mathrm{Ud} \mid \mathrm{Ppi} \cap \mathrm{Cr})=0$; and $\mathrm{P}$ (Ui $\mid$ Ppi $\cap \mathrm{Cr})=42.11 \%$.

For the water samples in compliance with the rules, only tank "B" was approved for fecal coliform parameters. For total dissolved solids, with a limit of $0.5 \mathrm{mg} \mathrm{mL}^{-1}$ (CONAMA, 2005), the average value was much lower in tank " $\mathrm{B}$ ", with $0.07 \mathrm{mg}$ $\mathrm{mL}^{-1}$, compared to $0.1 \mathrm{mg} \mathrm{mL}^{-1}$ in reservoir " $\mathrm{C}$ " and $0.08 \mathrm{mg} \mathrm{mL}^{-1}$ in the natural body of water. For the $\mathrm{pH}$ and average turbidity, the average values were within the ranges permissible by legislation for each site.

In reservoir "C", the contamination was highest from runoff, particularly for long periods of heavy rainfall before sampling (Figure 1), which led to the highest contamination of the reservoirs for fecal coliforms, and the difference was significant at $5 \%$.

Although fecal coliforms were found in many samples throughout 2013, particularly following concentrated rainy periods before sampling, the values were relatively low. However, the recommendation for the consumption of raw vegetables produced in this region is that they should be carefully washed and disinfected to eliminate microbial contamination. The contamination problems in the reservoirs primarily occurred after long periods of heavy rainfall when the requirements for irrigation decreased. Thus, the analysis of the periods of contamination in the reservoirs would be worthy of future study. The results of this study

Ciência Rural, v.46, n.4, abr, 2016. 
indicated the importance of preserving the water quality in the region to the local government.

\section{CONCLUSION}

High land use and weekly above average rainfalls affected the water quality and increased the probability that fecal coliform numbers would be above those allowed by legislation in the reservoirs (Resolution 357 of 2005, CONAMA).

The water from only one of the reservoirs (reservoir "B") was in compliance with the legislation (Resolution 357 of 2005 CONAMA) for fecal coliform parameters, which indicates need for environmental preservation to conserve the water quality in this region. However, the total dissolved solids, $\mathrm{pH}$ and turbidity were within the ranges permitted by the legislation.

\section{ACKNOWLEDGEMENTS}

The authors thank Coordenação de Aperfeiçoamento de Pessoal de Nível Superior (CAPES) e Conselho Nacional de Pesquisa e Desenvolvimento (CNPq).

\section{REFERENCES}

APHA (AMERICAN PUBLIC HEALTH ASSOCIATION). Standard methods for the examination of water and wastewater. 18.ed. Washington, D. C., 1992.937p.

BONILHA, P.R.M.; FALCÃO, D.P. Ocorrência de enteropatógenos em alfaces e suas águas de irrigação. Alim Nutr, v.5, p.87-97, 1994. Available from: <http://200.145.71.150/seer/index.php/ alimentos/article/view/726/615>. Accessed: Feb. 17, 2012.

COMEC (COORDENAÇÃO DA REGIÃO METROPOLITANA DE CURITIBA). Municípios da Região Metropolitana de Curitiba. Available from: <http://www.comec.pr.gov.br/modules/conteudo/ conteudo.php?conteudo=158>. Accessed: Feb. 23, 2014.

CONAMA (CONSELHO NACIONAL DO MEIO AMBIENTE). Resolução n. 357 de 17 de março de 2005. Estabelece a classificação das águas doces, salobras e salinas. Diário oficial da República Federativa do Brasil, Brasília, 17 de março, 2005.

EMBRAPA (CENTRO NACIONAL DE PESQUISA DE SOLOS). Sistema brasileiro de classificação de solos. 2.ed. Brasília: Embrapa Produção de Informação, 2006. 306p.

GONÇALVES, C.S. et al. Qualidade da água numa microbacia hidrográfica de cabeceira situada em região produtora de fumo. $\mathbf{R}$
Bras de Eng Agrícola e Ambiental, v.9, n.3, p.391-399, 2005. Available from: <http://www.scielo.br/pdf/rbeaa/v9n3/v9n3a15. pdf>. Accessed: Ago. 25, 2012.

IAPAR (INSTITUTO AGRONÔMICO DO PARANÁ). Agrometereologia. Available from: <http://www.iapar.br/ modules/conteudo/conteudo.php?conteudo $=677>$. Accessed: Mar. 12, 2014.

JAREK, T.M. Microbiologia da água de reservatórios, utilizados para irrigação de hortaliças, e uso do solo em sub-bacias de São José dos Pinhais. 2014. 40f. Dissertação (Mestrado em Ciência do Solo) - Universidade Federal do Paraná, Curitiba, PR.

LEPSCH, I.F.; BELLINAZZI JÚNIOR, R. Manual para levantamento utilitário do meio físico e classificação de terras no sistema de capacidade de uso. Campinas: Sociedade Brasileira de Ciencia do Solo, 1991. 175p.

OLIVEIRA, L.C. de et al. Variação espacial e temporal dos fatores limnológicos em riachos da microbacia do Rio São Francisco verdadeiro. Eng Agríc, v.28, n.4, p.770-781, 2008. Available from: <http://www.scielo.br/pdf/eagri/v28n4/17.pdf>. Accessed: May. 22, 2012. doi: S0100-69162008000400017.

PINTO, D.B.F. et al. Qualidade da água do Ribeirão Lavrinha na Região Alto Rio Grande - MG, Brasil. R. Ciênc e Agrotec, v.3, n.4 p.1145-1152, 2009. Available from: <http://www.scielo.br/pdf/ cagro/v33n4/a28v33n4.pdf $>$. Accessed: Mar. 12, 2014.

SANTOS, A.F.; BERTOTTI, L.G. Avaliação socioambiental da bacia hidrográfica do rio Pequeno, São José dos Pinhais (PR). R. Ambiência, v.5, n.2, p.275-292, 2009.

SANTOS, E.E.F; RIBEIRO, M.R. Influência da irrigação e do cultivo nas propriedades de um Latossolo e um Argissolo da Região do Submédio São Francisco: atributos morfológicos e físicos. R Bras Ci Solo, v.24, p.875-884, 2000. Available from: <http://sbcs.solos.ufv.br/solos/ revistas/v24n4a19.pdf>. Accessed: Jan. 23, 2014.

SEAB (SECRETARIA DA AGRICULTURA E DO ABASTECIMENTO DO PARANÁ). Valor bruto da produção agropecuária. Available from: <http://www.agricultura.pr.gov.br/>. Accessed: Feb. 23, 2014.

SILVA, P.I.A.P. et al. Águas de irrigação de hortas e de Lactuca sativa (alface) nas cidades de Catu e Alagoinhas - Bahia, Brasil. Rev Ciênc Méd Biol, v.9, n.3, p.194-199, 2010. Available from: $<$ https://repositorio.ufba.br/ri/bitstream/ri/1680/1/5159-13520-1PB.pdf>. Acessed: May 22, 2012.

SOUZA, J.L.M. Fundamentos de matemática e estatística para formulação de modelos e análise de dados: aplicado às ciências agrárias. Curitiba: DSEA/SCA/UFPR, 2013. 313p. (Série Didática). 